\title{
EU cohesion policy as a requirement to voivodeship development pathways
}

\begin{abstract}
Poland joined the European Union on 1 May 2004. By 2007, this had resulted in Poland being the greatest beneficiary of the European cohesion policy due to its low per capita GDP by purchasing power parity at the voivodeship level. The scale of European Structural and Investment Funds brought the possibility for a fundamental acceleration of socio-economic growth in Polish regions. The European Union gradually modified the directions of intervention under the framework of the European cohesion policy, initially orienting this activity principally towards cohesion, but from 2010 directing it mainly towards competitiveness. Of particular significance was the Europe 2020 strategy (2010). In Poland its arrangements were deferred until the signing of the Partnership Agreement for the period 2014-2020, which established extensive support for innovation, competitiveness and the R\&D sector. In the final part of the paper, conclusions and recommendations for regional policy are elaborated
\end{abstract}

Keywords

Territorial capital $\bullet$ cohesion policy $\bullet$ less developed regions $\bullet$ place based policy $\bullet$ regional development

(c) University of Warsaw - Faculty of Geography and Regional Studies

Introduction

One of the basic catalysts in the socio-economic development of Poland and its regions has been the European Union, and the European cohesion policy is of key importance. The most significant measure of convergence processes is per capita gross national product by purchasing power parity. The aim of this paper is to formulate conclusions on voivodeship development trajectories subsequent to Poland's 2004 accession to the EU, and recommendations for regional policy.

The European territorial context to development policy

As early as the 1957 Treaty of Rome, it was stated that the member states were: "Anxious to strengthen the unity of their economies and to ensure their harmonious development by reducing the differences existing between the various regions and the backwardness of the less favoured regions" (European Community 1957). In the Treaty on European Union, as it was passed in 1992, article 130A stated: "In order to promote its overall harmonious development, the Community shall develop and pursue its actions leading to the strengthening of its economic and social cohesion. In particular, the Community shall aim at reducing disparities between the levels of development of the various regions and the backwardness of the least favoured regions, including rural areas" (European Union 1992).

These treaties allowed an active cohesion policy to be implemented across Europe. One element of the intervention was the creation of structural funds: the European Social Fund in 1958, the European Agricultural Guidance and Guarantee Fund - Guidance Section in 1964, and the European Regional Development Fund in 1975.
Jacek Szlachta

Warsaw School of Economics, Collegium of Socio-Economics, Department of Regional and Spatial Development, Poland e-mail: jacek.szlachta@sgh.waw.pl

Received: 24 February 2017 Accepted: 22 May 2017

Of vital importance was the reform helping to introduce the European Union, known as the Delors package of 1989. It was oriented towards the weakest areas, specifically those whose per capita gross domestic product (GDP) by purchasing power parity as measured for NUTS 2 regions did not exceed $75 \%$ of the EU average $^{1}$. A basic part of the structural funds was allocated as national financial envelopes for these member states, which often concentrated their intervention on regional operational programmes. The Cohesion Fund was also created for dedication to environmental and transport infrastructure, and allocated and disbursed at the member state level. A long-term perspective financial model was also introduced to cover the following periods: 1989-1993, 1994-1999, 2000-2006, 2007-2013 and 20142020. Thanks to the Delors reform, the issue of the civilizational, economic and social foundations of regional development, and reduction of disparities on the national, regional and sub-regional level were all effectively addressed.

In the twenty-first century, there was a fundamental modification to the directions of EU structural interventions, due to economic megatrends disadvantageous for Europe, new theoretical inspirations and the global economic crisis.

In the formative milieu of the new generation of challenges to the EU and its member states, of key importance were the technological confrontation with the USA and Japan and the

${ }^{1}$ Nomenclature of Units for Territorial Statistics - universal regionalisation of the EU for the following region types: NUTS 1 (macroregions), NUTS 2 (regions) and NUTS 3 (subregions), which are one of the foundations of the European cohesion policy. As of 1 January 2015 there exist for these three regional levels, respectively: 98, 276 and 1,342 territorial entities. In Poland there are 6,16 and 72 territorial entities, respectively. 
dynamic growth of newly industrialised states (NIS), such as Brazil, China and India. A strong attempt to respond to the deteriorating economic position of Europe was made with the Lisbon Strategy of 2000, which aimed to make the EU the most competitive global economy within ten years. The key to success was identified as increased and better directed funds for research and development and their effective transfer into the economy, fundamentally increasing EU innovation and competitiveness. However, the lack of implementation mechanisms for the Lisbon Strategy meant that in 2005 "The renewed Lisbon Growth and Jobs Strategy" was adopted, and executed through an open coordination method (Ministry of Economy and Labour 2005). These strategies were essentially a-spatial as they did not specify any territorial dimension and did not refer to the European cohesion policy.

The global economic crisis, which hit the European Union and its older member states particularly hard after 2007, reinforced a critical approach which questioned the raison d'être of the cohesion policy (Sapir et al. 2003; Financial Times 2009a, 2009b, 2009c). This made it clear that European Union policies required a fundamental modification towards competitiveness, stimulating innovation, the R\&D sector, the information society, and so on.

The low effectiveness of these two strategies and the fundamental changes within the context of global growth were the bases for the preparation and adoption in 2010 of a new generation of mid-term strategies known as Europe 2020, a basis for all policies of the organisation and its member states in the second decade of the twenty-first century (European Commission 2010). The significance of Europe 2020 is highlighted by its binding assumption that the purpose of the European cohesion policy and other European policies will primarily be the effective implementation of this strategy, and the far less frequent addition of its need to translate to the regional level. The priorities of the Europe 2020 strategy are stated as: (1) developing an economy based on knowledge and innovation; (2) promoting a more resource-efficient, greener and more competitive economy, and (3) fostering a high-employment economy delivering social and territorial cohesion.

The European cohesion policy is of course of key significance to the effective implementation of this strategy, as it administers essential funds and instruments. The means of determining the European cohesion policy are documented, among others, by the following excerpt of the strategy: "It is also essential that the benefits of economic growth spread to all parts of the Union, including its outermost regions, thus strengthening territorial cohesion," and "Economic, social and territorial cohesion will remain at the heart of the Europe 2020 strategy to ensure that all energies and capacities are mobilised and focused on the pursuit of the strategy's priorities." This signifies an acceptance of the assumption that the realisation of this strategy will be conducive to an improvement in the developmental trajectory, including for less developed regions.

Changes in the regional development policy doctrine are associated, among other things, with: a new economic geography, introducing the territorial dimension into the mainstream economy (Krugman 1995; Fujita, Krugman \& Venables 2001); place-based policy (Barca 2009); and space of flows (Castells 2008a \& Castells 2008b). Fundamentally, issues of territorial capital have been appreciated and recognised as a significant factor in the socio-economic development of regions and nations (Camagni 2008). The common denominator of these studies is that their authors adopt the assumption that territorial conditions are significant in socioeconomic development (territory matters).

Of particular importance for the translation of these new theoretical inspirations into public policy on the various spatial scales (international, national, regional and local) were international organisations such as the World Bank and the OECD (The World Bank 2009; Gill 2010; OECD 2009a \& OECD 2009b). The World Bank proposed, among other things, a fundamental appreciation of urban policy, indicating the importance of cities in socio-economic development. This is very powerfully illustrated by the difference in GDP per square kilometre. In turn, the OECD proposed a new paradigm for regional development (see Tab. 1). According to the OECD, we are currently dealing with a fundamentally changed context with regard to the main elements of regional policy, namely: objectives, territorial units of intervention, strategy paths, instruments employed and actors (OECD 2009a). The growing role of regional and local authorities is also becoming a standard of public policies.

This model has also been adopted by the European Union. Of key significance to the shape of EU intervention in the process of regional development in the period 2014-2020 is the general regulation relating to the European cohesion policy (European Commission 2011). It contains the proposal taken from the Europe 2020 strategy for the thematic concentration of intervention activities. This legislative act defines 11 thematic objectives. Thematic concentration is intended to counter the dispersion of European cohesion policy funds into less essential investment directions, which has thus far frequently prevented the attainment of the necessary critical mass of interventions in key areas and themes, as well as being intended to prevent the assignment of European funds to undertakings of low developmental impact.

The concept of territorial capital was introduced by the OECD (OECD 2001) for the determination of the tangible and intangible assets of an area. Territorial parameters are currently treated as a key factor in development processes (Capello 2011; Szlachta \& Zaucha 2010). In order to classify all the individual elements in terms of competitiveness in consumption and the degree of materiality/ tangibility, a territorial capital system was proposed by Camagni (2008). In the context of development programming it is important that the territorialisation of public policies and the broader determining of territorial potentials are increasingly significant in the effects of public intervention (territory matters) (Szlachta 2015 pp. 3-4). In achieving additional benefits, it is not only the level of development of territorial capital that is a determining factor, but also its structure - that is, its component elements (Fratesi \& Perucca 2014).

Table 1. The old and the new paradigm of regional policy according to the OECD

\begin{tabular}{|c|c|c|}
\hline Trait & Old & New \\
\hline Objectives & $\begin{array}{c}\text { Fixed-term } \\
\text { compensation in } \\
\text { backward regions }\end{array}$ & $\begin{array}{c}\text { Exploitation of } \\
\text { potentials and } \\
\text { strengthening of } \\
\text { competitiveness }\end{array}$ \\
\hline $\begin{array}{c}\text { Unit of } \\
\text { intervention }\end{array}$ & $\begin{array}{c}\text { Administrative } \\
\text { units }\end{array}$ & $\begin{array}{c}\text { Functional economic } \\
\text { areas }\end{array}$ \\
\hline Strategies & $\begin{array}{c}\text { Sectoral } \\
\text { approaches }\end{array}$ & $\begin{array}{c}\text { Integrated } \\
\text { development projects }\end{array}$ \\
\hline Tools & $\begin{array}{c}\text { Subsidies and } \\
\text { public aid }\end{array}$ & $\begin{array}{c}\text { Mix of soft and hard } \\
\text { capital }\end{array}$ \\
\hline Actors & $\begin{array}{c}\text { Central } \\
\text { government }\end{array}$ & $\begin{array}{c}\text { Multilevel public } \\
\text { administration }\end{array}$ \\
\hline
\end{tabular}

Source: OECD, 2009a, Regional Policy Challenges. New Issues and Good Practices, Paris, 30-31 March. 
Conclusions and recommendations for Polish regional policy

After accession to the EU Poland gradually became the biggest beneficiary of the European cohesion policy. In the period 2007-2013, about $50 \%$ of public investment was financed from ESIF funds, and in 2014-2020 this figure is about $40 \%$. In total, the annual average transfer of ESIF funds to Poland since 2007 has been around 10 billion EUR. Poland adopted a decentralised model of implementation in which a sizeable portion of the funds was administered at the regional level. In 2007-2013, budgetary allocation was about 18 billion EUR from the European Regional Development Fund for regional operational programmes (ROP) and almost 7 billion EUR from the European Social Fund for the Human Capital Operational Programme, while in the period 2014-2020 around 32 billion EUR is allocated for ROPs.

Based on the conducted analysis, the following conclusions can be drawn on the significance of the European cohesion policy as an important factor determining the developmental trajectory of voivodeships.

1. The process of convergence with the EU. After accession, all voivodeships experienced an accelerated pace of growth due to the scale and scope of structural changes, resulting in the improvement of their position in the EU with regard to per capita gross domestic product. After 2007, the crisis caused an economic slow-down, including in Poland, but paradoxically this accelerated the process of convergence as many relatively wealthier countries and regions of Europe recorded falling GDPs.

2. The territorial correctness of convergence processes. In the period 1997-2014, Poland improved its position relative to the EU 28 average by 24 percentage points, while the Masovian voivodeship improved by 46 percentage points and the Lublin and West Pomeranian voivodeships by 13 percentage points only (see Tab. 2). In the last two decades, the process of convergence has been quickest in voivodeships associated with large urban centres, while the slowest progress has occurred in the weaker regions of eastern Poland, which has led to increased inter-regional disparities.

3. The influence of changes in regional policy doctrine (Zaucha et al. 2015). This includes: the introduction of the territorial dimension, including territorial capital as a catalyst for development processes; the European cohesion policy embracing all regions; the appreciation of urban policy, which has facilitated the treatment of the largest urban centres as an engine for development processes.

4. The influence of changes in European cohesion policy priorities (Ministry of Development 2015). The weight of structural EU intervention has gradually been shifted from pro-cohesion operations to pro-competitiveness instruments (see Tab. 3). The subordination of the European cohesion policy to the Europe 2020 strategy has meant a strengthening of centralising tendencies, including at the European level, and an appreciation of stronger regions as natural places to concentrate innovation activities and the R\&D sector.

5. The influence of changes in the structure of European cohesion policy expenditures on long-term programming. In the period 2014-2020, Poland has so far recorded changes relative to 2007-2013 with regard to environments conducive to enterprise and innovation (see Tab. 3). Despite this, not only in 2007-2013 but also in 2014-2020, infrastructural networks remain the most important expenditure among ESIF funds in Poland (promotion of sustainable transport 23.8 billion EUR; support for scientific research 10.0 billion EUR; increasing SME competitiveness, agriculture and fisheries 9.4 billion EUR).
Table 2. Per capita GDP by purchasing power parity relative to EU $28^{*}=100$ in the years $1997-2014$ (in \%)

\begin{tabular}{|c|c|c|c|c|c|}
\hline Voivodeship & $\mathbf{1 9 9 7}$ & $\mathbf{2 0 0 8}$ & $\mathbf{2 0 1 2}$ & $\mathbf{2 0 1 4}$ & $\begin{array}{c}\text { Change in } \\
\text { percentage } \\
\text { points } \\
\text { 1997-2014 }\end{array}$ \\
\hline Masovia & 63 & 89 & 105 & 109 & +46 \\
\hline Lower Silesia & 46 & 60 & 75 & 76 & +30 \\
\hline Greater Poland & 46 & 59 & 70 & 73 & +27 \\
\hline Silesia & 50 & 61 & 70 & 71 & +21 \\
\hline Pomerania & 43 & 53 & 65 & 65 & +22 \\
\hline Łódź & 39 & 52 & 62 & 64 & +25 \\
\hline Lesser Poland & 39 & 49 & 58 & 61 & +22 \\
\hline Lubuskie & 40 & 48 & 55 & 57 & +17 \\
\hline $\begin{array}{c}\text { West } \\
\text { Pomerania }\end{array}$ & 44 & 51 & 55 & 57 & +13 \\
\hline $\begin{array}{c}\text { Kuyavia- } \\
\text { Pomerania }\end{array}$ & 39 & 49 & 54 & 55 & +16 \\
\hline Opole & 40 & 48 & 53 & 55 & +15 \\
\hline Świętokrzyskie & 33 & 45 & 49 & 50 & +17 \\
\hline Podlasie & 35 & 41 & 47 & 49 & +14 \\
\hline $\begin{array}{c}\text { Warmia- } \\
\text { Masuria }\end{array}$ & 35 & 42 & 47 & 49 & +14 \\
\hline Subcarpathia & 33 & 39 & 46 & 48 & +15 \\
\hline Lublin & 34 & 39 & 46 & 47 & +13 \\
\hline Poland & 44 & 56 & 66 & 68 & +24 \\
\hline
\end{tabular}

* all 28 countries were taken into account during the period 19972014.

Source: Own calculations based on the Central Statistical Office of Poland and the Statistical Office in Katowice, 1999-2015, Gross national product Regional accounts, Warsaw-Katowice.

Table 3. Share of EU expenditures on specific thematic areas in Poland in the years 2007-2013 and 2014-2020

\begin{tabular}{|c|c|c|}
\hline Thematic areas & 2007-2013 & 2014-2020 \\
\hline $\begin{array}{c}\text { Environment conducive to } \\
\text { enterprise and innovation }\end{array}$ & 23.2 & 24.9 \\
\hline $\begin{array}{c}\text { Social cohesion and } \\
\text { professional activity }\end{array}$ & 20.7 & 20.0 \\
\hline Network infrastructure & 42.2 & 34.7 \\
\hline $\begin{array}{c}\text { Environment and effective } \\
\text { resource management }\end{array}$ & 16.0 & 20.4 \\
\hline
\end{tabular}

Source: Ministry of Development, 2015, Programming of Financial Perspective 2014-2020. Partnership Agreement, Warsaw, December.

6. The global economic crisis. After 2007, the financial crisis was particularly painfully felt in the countries and regions of the European Union. It transpired that greater resistance to economic collapse was enjoyed by technologically advanced, multi-functional regions associated with major urban centres, while problem areas - poor, peripheral regions with weaker socio-economic structures and those devoid of metropolitan centres - fared considerably less well in the face of the economic crisis. 
7. The trap of middling development. In the second decade of the twenty-first century, a significant reduction in the dynamism of convergence processes has so far been recorded for Poland and its regions. This is probably associated with the exhausting of the extensive foundations and capacities to generate highly dynamic socio-economic growth that is also environmentally friendly. Without deep structural changes, it is not possible to overcome this development barrier (Geodecki et al. 2012).

Based on an assessment of the solutions to date, it can be stated that, with regard to the new model of regional policy in Poland:

- The intended regional policy model should be built on the stronger economic voivodeships (with their own revenue and the capacity for local law making). The role of government can then truly be directed towards strategic interventions and the creation of appropriate systemic solutions. It is therefore essential to emphasize interregional and intraregional policies.

- It is essential to progressively replace ESIF funds with national funds, taking the opportunity to make qualitative changes to the method of financing development policy, while still maintaining the model of a regional policy which encompasses all regions of Poland. This issue is of particular concern for the richest voivodeships in Poland, which after 2020 will not be able to benefit from generous assistance from ESIF funds.

- The processes of the convergence of Poland and its regions within the EU are under threat. A broader exploitation of territorial capital, including the potential of cities, is one of the key elements in escaping from the trap of middling development. Regional policy should be better tailored than it has been thus far to the developmental context of a given area. Therefore, urban policy and rural development policy should be integrated and equipped with the necessary tools and instruments.
- It is essential to make the development processes of regions, towns and rural areas more resilient to the interference of global and European processes, which are expressed as megatrends and generally disadvantageous to Poland. This should be achieved via properly selected and financed smart regional specializations.

- $\quad$ The ability to exploit unexpected development opportunities such as 'wild cards' and 'black swans' is a decisive factor in the improvement of the development trajectories of regions and other territorial units. Instruments such as venture capital should be widely implemented, including at regional level.

- $\quad$ The new paradigm is not favourable to peripheral and poorlydeveloped areas. This has been expressed in the recording in recent years of an increase in regional disparities at the national level. It is essential to work out a new approach to the challenges of development being faced by these areas. Special funds and instruments dedicated to the poorest cities and municipalities should be anticipated.

- It is essential to increase the capacity of local governments to create pro-development mechanisms for financing development in functional systems. Revitalisation requires a multi-level concept of public administration. An important element of this approach is the wider use of the concept of functional areas.

In summary, the scope of essential changes in the field of Poland's regional policy is a considerable challenge for all stakeholders in the processes of forming a beneficial regional and local development pathway.

\section{Acknowledgement}

This paper is based on the results of the "Changing innovation process models: A chance to break out of path dependency for less developed regions" research project funded by the National Science Centre, Poland, grant number DEC-2014/13/B/ HS5/03612. The grant was awarded to the University of Warsaw, Faculty of Geography and Regional Studies.

\section{References}

Barca, F 2009, An Agenda for a Regional Cohesion Policy. A place based approach to meeting European Union challenges and expectations, Independent Report prepared at the request of D. Huebner, Commissioner for Regional Policy, Brussels.

Camagni, R 2008, 'Regional Competitiveness: Towards a Concept of Territorial Capital', in Modelling regional scenarios for the enlarged Europe, eds R Camagni, R Capello, B Chizzolini \& U Fratesi, Springer, Berlin, pp. 33-48.

Capello, R 2011, 'Location, Regional Growth and Local Development Theories', Aestimum, vol. 58, pp. 1-25.

Castells, M 2008a, Siła tożsamości, PWN, Warszawa.

Castells, M 2008b, Społeczeństwo sieci, PWN, Warszawa.

European Commission 2010, Communication to the European Council. Europe 2020. A strategy for smart, sustainable and inclusive growth, European Commission, Brussels 3.3.2010, $\mathrm{KPM}(2010) 2020$ final.

European Commission 2011, Regulation of the European Parliament and of the Council on laying down general provisions on the European Regional Development Fund, the European Social Fund, the Cohesion Fund, the European Agricultural Fund for Rural Development and the European Maritime and Fisheries Fund covered by the Common Strategic Framework and laying down general provisions on the European Regional Development Fund, the European Social Fund and the Cohesion Fund and repealing Regulation (EC) No 1083/2006, SEC(2011)1141, SEC(2011)1142, Brussels, $6.10 \mathrm{COM}(2011) 615$ final.

Financial Times 2010a, Grand vision loses focus in opaque system, November 30, p. 8-9.

Financial Times 2010b, Questions surround relocations. Multinationals reap the rewards, December 2, p. 8-9.

Financial Times 2010c, Cohesion for a reason, December 3, p. 9.

Fratesi, U \& Perucca, G 2014, 'Territorial Capital and the Effectiveness of Cohesion Policies: an Assessment for CEE Regions', Investigaciones Regionales, vol. 29, pp. 165-191.

Fujita, M, Krugman, P \& Venables, A, J 2001, The Spatial Economy. Cities, Regions and International Trade, The MIT Press, Cambridge - London, 2001.

Geodecki, T, Gorzelak, G, Górniak, J, Hausner, J, Mazur, S, Szlachta, J \& Zaleski, J, 2012, Kurs na innowacje. Jak wyprowadzić Polske z rozwojowego dryfu?, Fundacja Gospodarki i Administracji Publicznej Uniwersytetu Ekonomicznego w Krakowie, Kraków.

Gill, J 2010, Regional development policies: place-based or people-centered, The World Bank, Washington D. C.

Krugman, P 1995, Development, Geography and Economic Theory, The Massachusetts Institute of Technology Press, Cambridge. 
Ministerstwo Gospodarki i Pracy, 2005, Wspólne działania na rzecz wzrostu gospodarczego i zatrudnienia. Nowy początek strategii lizbońskiej. Komunikat na wiosenny szczyt Rady Europejskiej, Komisja Wspólnot Europejskich, Bruksela 2.2. $\operatorname{COM}(2005) 24$ końcowy, Warszawa.

Ministerstwo Rozwoju 2015, Programowanie perspektywy finansowej 2014-2020. Umowa Partnerstwa, Warszawa.

OECD 2001, Territorial Outlook. Territorial Economy, OECD, Paris.

OECD 2009a, Regional Policy Challenges. New Issues and Good Practices, Paris, 30-31.

OECD 2009b, How Regions Grow. Trends and Analysis, Paris.

Sapir, A, Aghion, P, Bertola, G, Hellwig, M, Pisani-Ferry, J, Rosati, D, Vinals, J \& Wallace, H 2003, 'An Agenda for a Growing Europe: Making the EU Economic System Deliver', Report of an Independent High-Level Study Group to the President of the European Commission, Brussels.

Szlachta, J 2015, 'Recommendations for applying territorial cohesion concept for conducting development policy. Territorial aspects of public policies', Working Papers, no. 016/2015, Institute for Development, Sopot.

Szlachta, J \& Zaucha, J 2010, 'A new Paradigm of the EU regional development in the context of the Poland's National Spatial Development Concept', Working Papers, no. 001/2010, Institute for Development, Sopot.

Unia Europejska 1992, Traktat o Unii Europejskiej, Maastricht, 7 luty.

The World Bank 2009, World Development Report 2009. Reshaping Economic Geography, Washington D. C.

Wspólnota Europejska 1957, Traktat ustanawiający Europejską Wspólnotę Gospodarczą, Rzym, 25.03.1957, Akty podstawowe prawa Unii Europejskiej, Dziennik Ustaw, Załącznik nr 2 do nru 90, 30.04.2004, poz. 864 , T. I, s. 10

Zaucha, J, Brodzicki, T, Ciołek, D, Komornicki, T, Mogiła, Z, Szlachta, J \& Zaleski, J 2015, Terytorialny wymiar wzrostu i rozwoju, Difin, Warsaw. 